\title{
Studi Persepsi Risiko pada Proyek Konstruksi Bidang Pengairan Di Sumatera Barat
}

\author{
Dwi Putri Nengsi ${ }^{1}$, Taufika Ophiyandri \\ ${ }^{1}$ Mahasiswa S2 Program Studi Teknik Sipil Fakultas Teknik Universitas Andalas \\ ${ }^{2}$ Dosen Program Studi Teknik Sipil Fakultas Teknik Universitas Andalas \\ Correspondence email: dwiputrinengsi@gmail.com
}

\begin{abstract}
Abstrak. Industri konstruksi memiliki lebih banyak risiko dibanding industri yang lain. Risiko merupakan peristiwa yang tidak diharapkan karena mengandung ketidakpastian. Contoh risiko yang tidak diketahui kapan terjadinya adalah banjir. Menurut data BNPB dalam lima tahun terakhir, tren bencana banjir di Sumatera Barat cenderung meningkat. Kejadian banjir memiliki risiko yang besar dalam pelaksanaan proyek khususnya bidang pengairan. Untuk itu sangat penting mengidentifikasi dan mengetahui persepsi pengguna jasa maupun penyedia jasa dalam memandang risiko. Sehingga dapat menentukan dengan benar pihak yang paling bertanggung jawab dalam memitigasi risiko. Penelitian ini bertujuan untuk mengidentifikasi persepsi risiko dari pengguna jasa dan penyedia jasa. Pengumpulan data menggunakan kuesioner yang disebar kepada pengguna jasa dan penyedia jasa yang terlibat dalam proyek pengairan di Sumatera Barat. Faktor-faktor risiko diperoleh dari studi literatur dan penelitian terdahulu. Pengolahan data dengan cara analisis data parametrik dan nonparametrik menggunakan program statistik SPSS. Hasil penelitian menunjukan bahwa keadaan cuaca hujan lebat merupakan risiko paling sering terjadi. Sedangkan risiko yang sangat berdampak terhadap waktu pelaksanaan konstruksi adalah rumitnya masalah perijinan atau pembebasan lahan, Responden konsisten dalam menentukan risiko yang harus dibagi atau ditanggung oleh pengguna atau penyedia jasa. Namun, ditemukan bahwa banyak risiko diputuskan secara ragu-ragu dan responden memiliki persepsi yang berbeda mengenai risiko.
\end{abstract}

Kata Kunci: Risiko, Konstruksi, Pengguna Jasa, dan Penyedia Jasa

\section{PENDAHULUAN}

Proyek konstruksi merupakan suatu rangkaian kegiatan unik yang hanya satu kali dilaksanakan (tidak berulang) dan memiliki tingkat kompleksitas yang tinggi. Nugrahaeni (2012) menjelaskan bahwa tingkat kompleksitas suatu proyek dipengaruhi oleh jumlah dan macam kegiatan didalam proyek, jumlah dan macam hubungan antar kelompok kegiatan, jumlah dan macam hubungan kelompok kegiatan didalam proyek dengan pihak luar. Karena tingginya tingkat kompleksitas tersebut sehingga setiap pelaksanaan proyek konstruksi tidak terlepas dari berbagai risiko. Risiko merupakan suatu peristiwa yang tidak diharapkan, karena berhubungan dengan ketidakpastian. Hal ini terjadi karena kurang atau tidak tersedianya cukup informasi tentang apa yang akan terjadi. Risiko yang terjadi akan berdampak pada terganggunya kinerja proyek secara keseluruhan sehingga dapat menimbulkan kerugian terhadap biaya, waktu dan kualitas pekerjaan.

Salah satu contoh risiko adalah kejadian banjir. Kejadian banjir di Indonesia utamanya disebabkan oleh curah hujan yang tinggi (Kodoatie dan Sugiyanto, 2002). Tingginya curah hujan mengakibatkan banjir dan genangan. Menurut data BNPB dalam lima tahun terakhir, tren bencana banjir di daerah Sumatera Barat cenderung meningkat. Kejadian bencana banjir memiliki risiko yang besar dalam pelaksanaan proyek konstruksi bidang pengairan. Khususnya pekerjaan konstruksi di Sungai, seperti pembangunan cekdam, groundsill, bendung. Dalam pelaksanaan di lapangan untuk membangun di sungai dilakukan pekerjaan kisdam untuk mengalihkan aliran air sungai. Pekerjaan kisdam merupakan pekerjaan yang sifatnya sementara sehingga banyak dari penyedia jasa tidak mempertimbangkan jika terjadi banjir. Akibatnya dapat merusak konstruksi yang sedang dibangun.

\section{Tujuan Penelitian}

Penelitian ini bertujuan untuk memaparkan persepsi risiko dari pengguna jasa dan penyedia jasa pada proyek konstruksi bidang pengairan di Sumatera Barat. Mengidentifikasi faktor-faktor risiko yang paling sering terjadi, mengidentifikasi faktor-faktor risiko yang paling berdampak terhadap waktu pelaksanaan proyek dan mengevaluasi pandangan pengguna jasa dan penyedia jasa dalam melihat alokasi risiko. Batasan masalah pada penelitian ini meliputi:

1. Proyek konstruksi yang akan ditinjau dibatasi pada pekerjaan konstruksi bidang pengairan.

2. Pihak-pihak yang terlibat adalah pengguna dan penyedia jasa yang memiliki pengalaman dalam pekerjaan konstruksi bidang pengairan di daerah Sumatera Barat.

3. Pengguna jasa berasal dari Balai Wilayah Sungai Sumatera V dan Dinas Pengelolaan Sumber Daya Air Provinsi Sumatera Barat. Sedangkan Penyedia Jasa merupakan pihak yang sedang melaksankan pekerjaan pada instansi pengguna jasa tersebut.

4. Data penelitian diperoleh dengan menggunakan kuesioner yang dibagikan kepada pihak yang terlibat sesuai dengan instansi yang disebutkan pada poin nomor 3 diatas. 
5. Metode pengolahan data dengan cara analisis data parametrik dan nonparametrik menggunakan software statstik SPSS (Statistical Program for Social Science) for Windows Version 24.

\section{TINJAUAN PUSTAKA}

Risiko merupakan suatu peristiwa yang mengandung ketidakpastian. Menurut Flanagan (1993) proses terjadinya risiko dapat diketahui dari tiga faktor yaitu, dari sumbernya, peristiwa/kejadiannya (event), dan akibat yang ditimbulkan. Penelitian mengenai risiko pada proyek konstruksi sudah dilakukan oleh beberapa peneliti terdahulu. Hasil identifikasi risiko pada proyek bidang pengairan dari beberapa penelitian terdahulu disusun dalam Tabel 1 dibawah:

\begin{tabular}{|c|c|c|c|c|c|c|}
\hline \multirow{2}{*}{ No } & \multirow{2}{*}{$\begin{array}{l}\text { Kode } \\
\text { Risiko }\end{array}$} & \multirow{2}{*}{ Jenis Risiko } & \multicolumn{4}{|c|}{ Sumber Literatur } \\
\hline & & & 1 & 2 & 3 & 4 \\
\hline 1 & RSK 01 & Keadaan cuaca hujan lebat & & $\sqrt{ }$ & $\sqrt{ }$ & \\
\hline 2 & RSK 02 & Bencana alam (seperti banjir, longsor, gempa bumi, dll) & & $\sqrt{ }$ & $\sqrt{ }$ & \\
\hline 3 & RSK 03 & Kondisi site / tanah yang tidak terduga & & & $\sqrt{ }$ & \\
\hline 4 & RSK 04 & Akses ke lokasi yang jelek dan sangat jauh & $\sqrt{ }$ & $\sqrt{ }$ & & \\
\hline 5 & RSK 05 & Kurangnya jumlah pekerja \& tenaga ahli & & $\sqrt{ }$ & $\sqrt{ }$ & $\sqrt{ }$ \\
\hline 6 & RSK 06 & Terjadinya pemogokan tenaga kerja & & $\sqrt{ }$ & $\sqrt{ }$ & \\
\hline 7 & RSK 07 & Rendahnya produktivitas pekerja & $\sqrt{ }$ & $\sqrt{ }$ & & \\
\hline 8 & RSK 08 & Hasil pekerjaan yang buruk & $\sqrt{ }$ & $\sqrt{ }$ & & \\
\hline 9 & RSK 09 & Penempatan tenaga kerja yang tidak sesuai dibidangnya & $\sqrt{ }$ & $\sqrt{ }$ & & \\
\hline 10 & RSK 10 & $\begin{array}{l}\text { Kenaikan harga material sehingga tidak sesuai lagi } \\
\text { dengan BQ (Bill of Quantity) }\end{array}$ & & $\sqrt{ }$ & $\sqrt{ }$ & $\sqrt{ }$ \\
\hline 11 & RSK 11 & Rendahnya kualitas material & $\sqrt{ }$ & $\sqrt{ }$ & & \\
\hline 12 & RSK 12 & Terlambat dalam pengiriman material & $\sqrt{ }$ & $\sqrt{ }$ & $\sqrt{ }$ & $\sqrt{ }$ \\
\hline 13 & RSK 13 & Kerusakan / kehilangan material selama penyimpanan & & $\sqrt{ }$ & & $\sqrt{ }$ \\
\hline 14 & RSK 14 & Alat yang digunakan tidak sesuai dengan spesifikasi & $\sqrt{ }$ & & & \\
\hline 15 & RSK 15 & Rendahnya produktivitas dan efisiensi & $\sqrt{ }$ & $\sqrt{ }$ & & \\
\hline 16 & RSK 16 & Sering out of order atau terjadinya kerusakan alat & & $\sqrt{ }$ & & \\
\hline 17 & RSK 17 & Tidak tersedianya suku cadang & & $\sqrt{ }$ & & \\
\hline 18 & RSK 18 & Jumlah peralatan kurang dari yang dibutuhkan & $\sqrt{ }$ & & & \\
\hline 19 & RSK 19 & $\begin{array}{l}\text { Keadaaan keuangan penyedia jasa yang buruk atau } \\
\text { penyedia jasa mengalami kepailitan }\end{array}$ & & $\sqrt{ }$ & & $\sqrt{ }$ \\
\hline 20 & RSK 20 & Kurangnya keterampilan teknis yang diperlukan & & $\sqrt{ }$ & $\sqrt{ }$ & \\
\hline 21 & RSK 21 & Masalah komunikasi dan koordinasi yang kurang baik & $\sqrt{ }$ & $\sqrt{ }$ & & $\sqrt{ }$ \\
\hline 22 & RSK 22 & Tidak memiliki kemampuan manejerial yang baik & $\sqrt{ }$ & $\sqrt{ }$ & $\sqrt{ }$ & $\sqrt{ }$ \\
\hline 23 & RSK 23 & Perubahan desain & & $\sqrt{ }$ & & $\sqrt{ }$ \\
\hline 24 & RSK 24 & Data desain tidak lengkap & & & $\sqrt{ }$ & \\
\hline 25 & RSK 25 & Keterlambatan pembayaran oleh pemilik & & & & $\sqrt{ }$ \\
\hline 26 & RSK 26 & Gangguan keamanan & & $\sqrt{ }$ & & \\
\hline 27 & RSK 27 & Protes atau pelarangan pekerjaan oleh warga sekitar & & & $\sqrt{ }$ & \\
\hline 28 & RSK 28 & Kecelakaan pekerja & & $\sqrt{ }$ & $\sqrt{ }$ & \\
\hline 29 & RSK 29 & Terjadinya perselisihan antar pekerja & & & & $\sqrt{ }$ \\
\hline 30 & RSK 30 & Spesifikasi teknis kurang lengkap & $\sqrt{ }$ & $\sqrt{ }$ & & \\
\hline 31 & RSK 31 & $\begin{array}{l}\text { Ketidaksesuaian antara spesifikasi, gambar dan Bill of } \\
\text { Quantity }\end{array}$ & & & $\sqrt{ }$ & $\sqrt{ }$ \\
\hline 32 & RSK 32 & Klausa kontrak yang ambigu dan memiliki beberapa arti & & $\sqrt{ }$ & $\sqrt{ }$ & \\
\hline 33 & RSK 33 & Perubahan peraturan pemerintah & & & & $\sqrt{ }$ \\
\hline 34 & RSK 34 & Rumitnya masalah perijinan atau pembebasan lahan & & $\sqrt{ }$ & & \\
\hline 35 & RSK 35 & Ketidakstabilan moneter dan Inflasi & & & & $\sqrt{ }$ \\
\hline
\end{tabular}

Keterangan

$1=$ Masril (2012)

2 = Nizamuddin $(2013)$

$3=$ Honesti (2014)

4 = Ratnaningsih (2014)

Penelitian sekarang berbeda dengan penelitian-penelitian sebelumnya. Data diperoleh dengan metode kuesioner. Proyek konstruksi yang diteliti adalah pada proyek bidang pengairan di Sumatera Barat. 


\section{METODE}

Data yang digunakan dalam peneltian ini bersumber dari data primer dan data sekunder. Data primer diperoleh dari hasil kuesoner yang dibagikan langsung ke responden. Data sekunder berasal dari studi literatur berupa penelitian terdahulu. Hasil identifikasi risiko pada proyek bidang pengairan dari beberapa penelitian terdahulu dapat dilihat pada Tabel 1. Pengumpulan data primer dilakukan dengan menyebarkan kuesioner ke 50 responden. Tingkat pengembalian data dari 50 kuesioner yang telah disebarkan yakni sebesar $86 \%$ dengan 7 buah kuesioner yang tidak lengkap. Pengolahan data survei dilakukan dengan menggunakan program SPSS (Statistical Program for Social Science). Analisis yang dilakukan adalah analisis data parametrik dan nonparametrik. Analisis data parametrik berupa uji validitas dan reliabilitas, uji normalitas dan homogenitas. Analisis nonparametrik yang dilakukan adalah analisis statistik deskriptif untuk menghitung nilai rata-rata dari probabilitas dan dampak faktor risiko. Sedangkan untuk mengetahui alokasi risiko dilakukan uji Chi Square. Penilaian alokasi risiko menggunakan Uji Chi Square. Mengacu ke penelitian Andi (2006) bahwa Hipotesis nol (H0) adalah bahwa tidak ada perbedaan antara tiga kategori (pengguna jasa, penyedia jasa, bersama). Oleh karena itu, untuk risiko yang akan dialokasikan ke dalam kategori tertentu, dua kondisi yang harus dipenuhi yakni:

1. Nilai rata-rata dalam kategori tertentu harus $>50 \%$

2. Perbedaan respon antara tiga kategori harus memiliki nilai Sig. (Signifikansi) $<0,05$

Faktor-faktor risiko yang tidak memenuhi dua kondisi diatas akan di tandai sebagai ragu-ragu.

\section{HASIL DAN PEMBAHASAN \\ Uji Validitas dan Reliabilitas}

Dari hasil analisis instrumen penelitian baik terhadap uji validitas maupun uji reliabilitas dinyatakan valid dengan nilai signifikansi koefisien korelasi item pertanyaan terhadap total item pertanyaan kurang dari 0,05 . Analisis terhadap uji reliabilitas diperoleh koefisien alpha (Croncbanch's Alpha) besar dari 0,7, maka alat ukur dalam penelitian dapat diterima.

\section{Frekuensi Risiko Berdasarkan Persepsi Pengguna jasa dan Penyedia jasa}

Tabel 2 merupakan persepsi pengguna jasa dan penyedia jasa dari faktor-faktor risiko yang paling sering terjadi pada pelaksanaan pekerjaan konstruksi bidang pengairan di Sumatera Barat. Faktor risiko yang paling sering terjadi adalah keadaan cuaca hujan lebat. Baik pengguna jasa maupun penyedia jasa memiliki persepsi yang sama. Nilai ratarata (mean value) pengguna jasa (nilai mean 3,70 ) lebih tinggi dari penyedia jasa (nilai mean 3,57 ). Peringkat kedua faktor risiko yang paling sering terjadi menurut pengguna jasa maupun penyedia jasa adalah bencana alam khususnya banjir dan longsor serta peringkat ketiga adalah keadaan keuangan penyedia jasa yang buruk. Sedangkan perbedaan persepsi antara pengguna jasa dan penyedia jasa yang memiliki perbedaan yang signifikan (uji mann whitney pada Sig. < 5\%) adalah tidak memiliki kemampuan manajerial yang baik dengan nilai Sig. 0,029 dan rendahnya produktif dan efisiensi dengan nilai Sig. 0,044. Pengguna jasa berpendapat masih banyak penyedia jasa yang memiliki manajerial yang kurang baik dan masih rendah produktifitas dan efisiensi. Hal ini dikarenakan sebagian dari penyedia jasa yang terlibat dalam proyek pengairan di Sumatera Barat merupakan penyedia jasa lokal yang masih memiliki keterbatasan modal maupun personil.

Tabel 2. Frekuensi Risiko Berdasarkan Persepsi Pengguna Jasa dan Penyedia Jasa

\begin{tabular}{|c|c|c|c|c|c|c|c|c|c|c|}
\hline \multirow[t]{2}{*}{$\begin{array}{c}\text { Kode } \\
\text { Risiko }\end{array}$} & \multirow[t]{2}{*}{ Faktor - Faktor Risiko } & \multirow{2}{*}{$\begin{array}{c}\text { Rata-Rata } \\
\text { Pengguna } \\
\text { Jasa }\end{array}$} & \multirow{2}{*}{$\begin{array}{l}\text { Rata-Rata } \\
\text { Penyedia } \\
\text { Jasa }\end{array}$} & \multirow{2}{*}{$\begin{array}{l}\text { Total } \\
\text { Rata- } \\
\text { Rata }\end{array}$} & \multirow[t]{2}{*}{ Sig. } & \multicolumn{5}{|c|}{$\begin{array}{c}\text { Rata-Rata dari } \\
\text { Pengguna Jasa dan } \\
\text { Penyedia Jasa }\end{array}$} \\
\hline & & & & & & 1 & 2 & 3 & 4 & 5 \\
\hline RSK 01 & Keadaan cuaca hujan lebat & 3,70 & 3,57 & 3,63 & 0,344 & & & & i9 & \\
\hline RSK 02 & Bencana alam (seperti banjir, longsor, dll) & 3,49 & 3,38 & 3,43 & 0,653 & & & & & \\
\hline RSK 03 & Kondisi site / tanah yang tidak terduga & 2,88 & 3,00 & 2,94 & 0,392 & & & & & \\
\hline RSK 04 & Akses ke lokasi yang jelek dan sangat jauh & 3,05 & 2,95 & 3,00 & 0,896 & & & & & \\
\hline RSK 05 & Perubahan desain & 3,37 & 3,10 & 3,23 & 0,645 & & & & & \\
\hline RSK 06 & Data desain tidak lengkap & 3,21 & 3,05 & 3,13 & 0,302 & & & & & \\
\hline RSK 07 & Keterlambatan pembayaran oleh pemilik & 2,58 & 2,57 & 2,58 & 0,970 & & & & & \\
\hline RSK 08 & Spesifikasi teknis kurang lengkap & 2,70 & 2,71 & 2,71 & 0,940 & & & & & \\
\hline RSK 09 & $\begin{array}{l}\text { Ketidaksesuaian antara spesifikasi, gambar } \\
\text { \& BoQ }\end{array}$ & 2,95 & 2,95 & 2,95 & 0,930 & & & & & \\
\hline
\end{tabular}


RSK 10 Klausa kontrak yang ambigu \& memiliki beberapa arti

RSK 11 Keadaaan keuangan kontraktor yang buruk

RSK 12 Kurangnya keterampilan teknis yang diperlukan

RSK 13 Masalah komunikasi dan koordinasi yang kurang baik

RSK 14 Tidak memiliki kemampuan manejerial yang baik

RSK 15 Kurangnya jumlah pekerja \& tenaga ahli

RSK 16 Terjadinya pemogokan tenaga kerja

RSK 17 Rendahnya produktivitas pekerja

RSK 18 Hasil pekerjaan yang buruk

RSK 19 Penempatan tenaga kerja yang tidak sesuai dibidangnya

RSK 20 Alat yang digunakan tidak sesuai dengan spesifikasi

RSK 21 Rendahnya produktivitas dan efisiensi

RSK 22 Sering out of order atau terjadinya kerusakan alat

RSK 23 Tidak tersedianya suku cadang

RSK 24 Jumlah peralatan kurang dari yang dibutuhkan

RSK 25 Kenaikan harga material sehingga tidak sesuai lagi dengan BQ (Bill of Quantity)

RSK 26 Rendahnya kualitas material

RSK 27 Terlambat dalam pengiriman material

RSK 28 Kerusakan / kehilangan material selama penyimpanan

RSK 29 Gangguan keamanan

RSK 30 Protes atau pelarangan pekerjaan oleh warga sekitar

RSK 31 Kecelakaan pekerja

RSK 32 Terjadinya perselisihan antar pekerja

RSK 33 Perubahan peraturan pemerintah

RSK 34 Rumitnya masalah perijinan atau pembebasan lahan

RSK 35 Ketidakstabilan moneter dan Inflasi
2,42

3,47

3,26

3,14

3,30

3,26

2,63

3,12

3,02

2,88

2,79

3,12

2,95

2,72

2,86

2,95

2,84

2,98

2,81

3,12

3,14

2,44

2,32

2,45

3,36

2,50
2,48

2,45

0,968

3,19

3,33

0.101

3,14

$3,20 \quad 0,610$

3,05

3,09

0,441

2,90

$3,10 \quad 0,029 *$

3,05

3,15

0,251

2,52

2,58

0,461

2,95

3,03

0,428

2,76

2,89

0,232

2,71

2,80

0,384

2,62

2,70

0,382

2,71

2,92

$0,044 *$

2,67

$2,81 \quad 0,204$

2,67

2,69

0,791

2,76

2,81

0,791

$2,90 \quad 2,93 \quad 0,613$

$2,62 \quad 2,73 \quad 0,139$

2,81

2,89 0,365

2,62

$2,72 \quad 0,277$

$2,90 \quad 3,01 \quad 0,283$

$3,00 \quad 3,07 \quad 0,536$

$2,43 \quad 2,44 \quad 0,970$

$2,33 \quad 2,33 \quad 0,920$

2,52

$2,49 \quad 0,950$

2,95

$3,16 \quad 0,256$

2,29

2,39

0,650

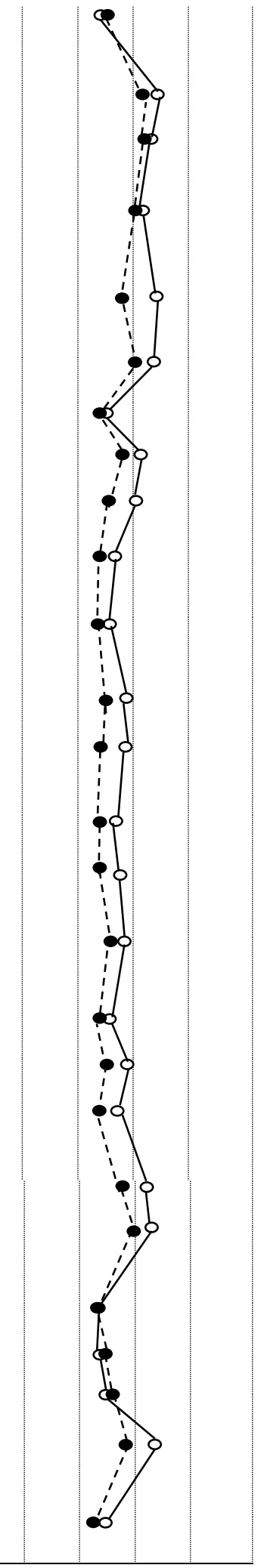

Pengguna Jasa Penyedia Jasa

\section{Dampak Risiko Terhadap Waktu Pelaksanaan Pekerjaan Berdasarkan Persepsi Pengguna jasa dan Penyedia Jasa}

Untuk mengetahui faktor-faktor risiko yang memiliki dampak yang besar terhadap waktu pelaksanaan pekerjaan berdasarkan persepsi pengguna dan penyedia jasa seperti Tabel 3. 
Tabel 3. Dampak Risiko Berdasarkan Persepsi Pengguna Jasa dan Penyedia Jasa

\begin{tabular}{|c|c|c|c|c|c|c|c|c|c|}
\hline \multirow[t]{2}{*}{$\begin{array}{l}\text { Kode } \\
\text { Risiko }\end{array}$} & \multirow[t]{2}{*}{ Faktor - Faktor Risiko } & \multirow{2}{*}{$\begin{array}{c}\text { Rata-Rata } \\
\text { Pengguna } \\
\text { Jasa }\end{array}$} & \multirow{2}{*}{$\begin{array}{c}\text { Rata- } \\
\text { Rata } \\
\text { Penyedia } \\
\text { Jasa }\end{array}$} & \multirow{2}{*}{$\begin{array}{l}\text { Total } \\
\text { Rata- } \\
\text { Rata }\end{array}$} & \multirow[t]{2}{*}{ Sig. } & \multicolumn{4}{|c|}{$\begin{array}{c}\text { Rata-Rata dari } \\
\text { Pengguna Jasa dan } \\
\text { Penyedia Jasa }\end{array}$} \\
\hline & & & & & & 12 & 3 & 4 & 5 \\
\hline RSK 01 & Keadaan cuaca hujan lebat & 4,23 & 3,95 & 4,09 & 0,302 & & & & \\
\hline RSK 02 & Bencana alam (seperti banjir, longsor, dll) & 4,14 & 4,10 & 4,12 & 0,812 & & & & \\
\hline RSK 03 & Kondisi site / tanah yang tidak terduga & 3,41 & 3,33 & 3,37 & 0,876 & & & & \\
\hline RSK 04 & Akses ke lokasi yang jelek dan sangat jauh & 3,32 & 3,33 & 3,33 & 0,807 & & & & \\
\hline RSK 05 & Perubahan desain & 3,55 & 3,48 & 3,51 & 0,713 & & & & \\
\hline RSK 06 & Data desain tidak lengkap & 3,50 & 3,38 & 3,44 & 0,730 & & & & \\
\hline RSK 07 & Keterlambatan pembayaran oleh pemilik & 3,36 & 3,05 & 3,21 & 0,390 & & & & \\
\hline RSK 08 & Spesifikasi teknis kurang lengkap & 2,55 & 2,86 & 2,70 & 0,248 & & & & \\
\hline RSK 09 & $\begin{array}{l}\text { Ketidaksesuaian antara spesifikasi, gambar } \\
\& \text { BoQ }\end{array}$ & 2,95 & 3,24 & 3,10 & 0,336 & & & & \\
\hline RSK 10 & $\begin{array}{l}\text { Klausa kontrak yang ambigu \& memiliki } \\
\text { beberapa arti }\end{array}$ & 2,55 & 2,81 & 2,68 & 0,404 & & & & \\
\hline RSK 11 & Keadaaan keuangan kontraktor yang buruk & 4,18 & 3,29 & 3,73 & $0,036^{*}$ & & & & \\
\hline RSK 12 & $\begin{array}{l}\text { Kurangnya keterampilan teknis yang } \\
\text { diperlukan }\end{array}$ & 3,77 & 3,86 & 3,81 & 0,545 & & & & \\
\hline RSK 13 & $\begin{array}{l}\text { Masalah komunikasi dan koordinasi yang } \\
\text { kurang baik }\end{array}$ & 3,55 & 3,48 & 3,51 & 0,832 & & & o & \\
\hline RSK 14 & $\begin{array}{l}\text { Tidak memiliki kemampuan manejerial } \\
\text { yang baik }\end{array}$ & 3,86 & 3,71 & 3,79 & 0,749 & & & & \\
\hline RSK 15 & Kurangnya jumlah pekerja \& tenaga ahli & 3,73 & 3,67 & 3,70 & 0,813 & & & & \\
\hline RSK 16 & Terjadinya pemogokan tenaga kerja & 3,45 & 3,71 & 3,58 & 0,345 & & & לִ & \\
\hline RSK 17 & Rendahnya produktivitas pekerja & 3,50 & 3,81 & 3,65 & 0,244 & & & 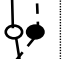 & \\
\hline RSK 18 & Hasil pekerjaan yang buruk & 3,59 & 3,43 & 3,51 & 0,596 & & & & \\
\hline RSK 19 & $\begin{array}{l}\text { Penempatan tenaga kerja yang tidak sesuai } \\
\text { dibidangnya }\end{array}$ & 3,45 & 3,67 & 3,56 & 0,443 & & & $\phi$ & \\
\hline RSK 20 & $\begin{array}{l}\text { Alat yang digunakan tidak sesuai dengan } \\
\text { spesifikasi }\end{array}$ & 3,45 & 3,48 & 3,47 & 0,778 & & & $\$$ & \\
\hline RSK 21 & Rendahnya produktivitas dan efisiensi & 3,77 & 3,90 & 3,84 & 0,562 & & & $\$$ & \\
\hline RSK 22 & $\begin{array}{l}\text { Sering out of order atau terjadinya } \\
\text { kerusakan alat }\end{array}$ & 3,73 & 3,81 & 3,77 & 0,809 & & & $\prod_{1}^{1}$ & \\
\hline RSK 23 & Tidak tersedianya suku cadang & 3,41 & 3,62 & 3,51 & 0,379 & & & & \\
\hline RSK 24 & $\begin{array}{l}\text { Jumlah peralatan kurang dari yang } \\
\text { dibutuhkan }\end{array}$ & 3,02 & 3,76 & 3,39 & $0,025^{*}$ & & & : & \\
\hline RSK 25 & $\begin{array}{l}\text { Kenaikan harga material sehingga tidak } \\
\text { sesuai lagi dengan BQ (Bill of Quantity) }\end{array}$ & 3,23 & 3,48 & 3,35 & 0,412 & & & 'ه & \\
\hline RSK 26 & Rendahnya kualitas material & 3,23 & 3,24 & 3,23 & 0,969 & & & & \\
\hline RSK 27 & Terlambat dalam pengiriman material & 3,59 & 3,67 & 3,63 & 0,769 & & & 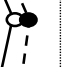 & \\
\hline RSK 28 & $\begin{array}{l}\text { Kerusakan / kehilangan material selama } \\
\text { penyimpanan }\end{array}$ & 3,36 & 3,57 & 3,47 & 0,357 & & & ti & \\
\hline RSK 29 & Gangguan keamanan & 3,59 & 3,48 & 3,53 & 0,721 & & & क & \\
\hline RSK 30 & Protes atau pelarangan pekerjaan oleh & 3,50 & 3,81 & 3,65 & 0,419 & & & di & \\
\hline
\end{tabular}




\begin{tabular}{|c|c|c|c|c|c|c|c|}
\hline & warga sekitar & & & & & & \\
\hline RSK 31 & Kecelakaan pekerja & 2,86 & 3,14 & 3,00 & 0,526 & $p$ & • \\
\hline RSK 32 & Terjadinya perselisihan antar pekerja & 2,77 & 2,95 & 2,86 & 0,607 & & \\
\hline RSK 33 & Perubahan peraturan pemerintah & 2,73 & 2,86 & 2,79 & 0,802 & & \\
\hline RSK 34 & $\begin{array}{l}\text { Rumitnya masalah perijinan atau } \\
\text { pembebasan lahan }\end{array}$ & 4,41 & 4,14 & 4,28 & 0,639 & & \\
\hline RSK 35 & Ketidakstabilan moneter dan Inflasi & 2,86 & 3,00 & 2,93 & 0,764 & & \\
\hline
\end{tabular}

Faktor risiko yang paling berpengaruhi terhadap waktu pelaksanaan pekerjaan adalah rumitnya masalah perijinan atau pembebasan lahan dengan nilai total rata-rata (mean) sebesar 4,28. Tidak sedikit pekerjaan konstruksi terhambat di lapangan dikarenakan masalah pembebasan tanah. Khususnya di Sumatera Barat masalah pembebasan tanah tergolong rumit karena sebagian tanah masyarakat merupakan tanah kaum atau tanah ulayat sehingga menyangkut banyak pihak. Masalah pembebasan tanah umumnya terjadi pada proyek bidang irigasi.

Bencana alam seperti banjir dan longsor berada diurutan kedua dengan nilai total rata-rata sebesar 4,12. Faktor risiko selanjutnya yang berdampak terhadap waktu adalah keadaan cuaca hujan lebat dengan nilai total rata-rata sebesar 4,09. Antara pengguna dan penyedia jasa sepakat bahwa jika terjadi hujan terus menerus akan mengganggu pekerjaan di lapangan. Khususnya pekerjaan sungai sangat berdampak jika terjadi hujan lebat, karena aliran air yang deras akan membuat pekerjaan terhenti.

Secara umum dari hasil penelitian terdapat persepsi yang hampir sama antara pengguna dan penyedia jasa namun terjadi perbedaan yang signifikan pada dua faktor risiko. Yang pertama adalah keadaan keuangan penyedia jasa yang buruk atau penyedia jasa mengalami kepailitan (uji mann whitney pada Sig. $<5 \%$ ) adalah 0,036. Terdapat perbedaan persepsi antara pengguna dan penyedia jasa. Nilai rata-rata pengguna jasa adalah 4,18 sedangkan nilai ratarata penyedia jasa sebesar 3,29. Yang kedua, adalah jumlah peralatan kurang dari yang dibutuhkan dengan nilai ratarata pengguna jasa sebesar 3,02 dan nilai rata-rata penyedia jasa sebesar 3,76.

\section{Alokasi Risiko}

Penilaian alokasi risiko menggunakan Uji Chi Square. Hipotesis nol (H0) adalah bahwa tidak ada perbedaan antara tiga kategori (pengguna jasa, penyedia jasa, bersama). Pada Tabel 4 ditampilkan perbandingan respon pandangan dari pengguna jasa dan penyedia jasa terhadap alokasi risiko.

Tabel 4. Perbandingan Persepsi Alokasi Risiko Antara Pengguna Jasa dan Penyedia

\begin{tabular}{|c|c|c|c|c|c|}
\hline \multirow{2}{*}{$\begin{array}{l}\text { Kode } \\
\text { Risiko }\end{array}$} & \multirow[b]{2}{*}{ Faktor - Faktor Risiko } & \multicolumn{2}{|c|}{ Aktual Alokasi } & \multicolumn{2}{|c|}{ Ekspektasi Alokasi } \\
\hline & & Pengguna Jasa & Penyedia Jasa & $\begin{array}{l}\text { Pengguna } \\
\text { Jasa }\end{array}$ & Penyedia Jasa \\
\hline \multicolumn{6}{|c|}{ A. Kondisi Lokasi /Site } \\
\hline RSK 01 & Keadaan cuaca hujan lebat & Ragu-Ragu & Penyedia Jasa & Ragu-Ragu & Ragu-Ragu \\
\hline RSK 02 & $\begin{array}{l}\text { Bencana alam (seperti banjir, longsor, } \\
\text { gempa bumi, dll) }\end{array}$ & Bersama & Bersama & Bersama & Bersama \\
\hline RSK 03 & Kondisi site / tanah yang tidak terduga & Penyedia Jasa & Penyedia Jasa & Bersama & Ragu-Ragu \\
\hline RSK 04 & Akses ke lokasi yang jelek dan sangat jauh & Penyedia Jasa & Ragu-Ragu & Ragu-Ragu & Ragu-Ragu \\
\hline \multicolumn{6}{|c|}{ B. Pengguna Jasa } \\
\hline RSK 05 & Perubahan desain & Ragu-Ragu & Ragu-Ragu & Bersama & Bersama \\
\hline RSK 06 & Data desain tidak lengkap & Ragu-Ragu & Ragu-Ragu & Bersama & Bersama \\
\hline RSK 07 & Keterlambatan pembayaran oleh pemilik & Ragu-Ragu & Ragu-Ragu & Ragu-Ragu & Ragu-Ragu \\
\hline \multicolumn{6}{|c|}{ C. Kontrak } \\
\hline RSK 08 & Spesifikasi teknis kurang lengkap & Ragu-Ragu & Ragu-Ragu & Ragu-Ragu & Ragu-Ragu \\
\hline RSK 09 & $\begin{array}{l}\text { Ketidaksesuaian antara spesifikasi, } \\
\text { gambar dan Bill of Quantity }\end{array}$ & Ragu-Ragu & Ragu-Ragu & Ragu-Ragu & Bersama \\
\hline RSK 10 & $\begin{array}{l}\text { Klausa kontrak yang ambigu dan memiliki } \\
\text { beberapa arti }\end{array}$ & Ragu-Ragu & Ragu-Ragu & Ragu-Ragu & Bersama \\
\hline
\end{tabular}




\begin{tabular}{|c|c|c|c|c|c|}
\hline \multirow{2}{*}{$\begin{array}{c}\text { Kode } \\
\text { Risiko }\end{array}$} & \multirow[b]{2}{*}{ Faktor - Faktor Risiko } & \multicolumn{2}{|c|}{ Aktual Alokasi } & \multicolumn{2}{|c|}{ Ekspektasi Alokasi } \\
\hline & & Pengguna Jasa & Penyedia Jasa & $\begin{array}{l}\text { Pengguna } \\
\text { Jasa }\end{array}$ & Penyedia Jasa \\
\hline \multicolumn{6}{|c|}{ D. Penyedia Jasa } \\
\hline RSK 11 & $\begin{array}{l}\text { Keadaaan keuangan kontraktor yang } \\
\text { buruk atau kontraktor mengalami } \\
\text { kepailitan }\end{array}$ & Penyedia Jasa & Penyedia Jasa & Ragu-Ragu & Ragu-Ragu \\
\hline RSK 12 & $\begin{array}{l}\text { Kurangnya keterampilan teknis yang } \\
\text { diperlukan }\end{array}$ & Penyedia Jasa & Penyedia Jasa & Penyedia Jasa & Ragu-Ragu \\
\hline RSK 13 & $\begin{array}{l}\text { Masalah komunikasi dan koordinasi yang } \\
\text { kurang baik }\end{array}$ & Ragu-Ragu & Ragu-Ragu & Ragu-Ragu & Ragu-Ragu \\
\hline RSK 14 & $\begin{array}{l}\text { Tidak memiliki kemanpuan manejerial } \\
\text { yang baik }\end{array}$ & Penyedia Jasa & Ragu-Ragu & Penyedia Jasa & Ragu-Ragu \\
\hline \multicolumn{6}{|c|}{ E. Tenaga Kerja \& Tenaga Ahli } \\
\hline RSK 15 & Kurangnya jumlah pekerja \& tenaga ahli & Penyedia Jasa & Penyedia Jasa & Penyedia Jasa & Ragu-Ragu \\
\hline RSK 16 & Terjadinya pemogokan tenaga kerja & Penyedia Jasa & Penyedia Jasa & Ragu-Ragu & Ragu-Ragu \\
\hline RSK 17 & Rendahnya produktivitas pekerja & Penyedia Jasa & Penyedia Jasa & Ragu-Ragu & Ragu-Ragu \\
\hline RSK 18 & Hasil pekerjaan yang buruk & Ragu-Ragu & Ragu-Ragu & Bersama & Ragu-Ragu \\
\hline RSK 19 & $\begin{array}{l}\text { Penempatan tenaga kerja yang tidak sesuai } \\
\text { dibidangnya }\end{array}$ & Penyedia Jasa & Ragu-Ragu & Bersama & Bersama \\
\hline \multicolumn{6}{|c|}{ F. Peralatan } \\
\hline RSK 20 & $\begin{array}{l}\text { Alat yang digunakan tidak sesuai dengan } \\
\text { spesifikasi }\end{array}$ & Penyedia Jasa & Penyedia Jasa & Ragu-Ragu & Ragu-Ragu \\
\hline RSK 21 & Rendahnya produktivitas dan efisiensi & Penyedia Jasa & Penyedia Jasa & Ragu-Ragu & Ragu-Ragu \\
\hline RSK 22 & $\begin{array}{l}\text { Sering out of order atau terjadinya } \\
\text { kerusakan alat }\end{array}$ & Penyedia Jasa & Penyedia Jasa & Ragu-Ragu & Ragu-Ragu \\
\hline RSK 23 & Tidak tersedianya suku cadang & Penyedia Jasa & Penyedia Jasa & Ragu-Ragu & Ragu-Ragu \\
\hline RSK 24 & $\begin{array}{l}\text { Jumlah peralatan kurang dari yang } \\
\text { dibutuhkan }\end{array}$ & Penyedia Jasa & Penyedia Jasa & Ragu-Ragu & Ragu-Ragu \\
\hline \multicolumn{6}{|c|}{ G. Material } \\
\hline RSK 25 & $\begin{array}{l}\text { Kenaikan harga material sehingga tidak } \\
\text { sesuai lagi dengan BQ (Bill of Quantity) }\end{array}$ & Penyedia Jasa & Penyedia Jasa & Ragu-Ragu & Bersama \\
\hline RSK 26 & Rendahnya kualitas material & Penyedia Jasa & Penyedia Jasa & Ragu-Ragu & Ragu-Ragu \\
\hline RSK 27 & Terlambat dalam pengiriman material & Penyedia Jasa & Penyedia Jasa & Penyedia Jasa & Penyedia Jasa \\
\hline RSK 28 & $\begin{array}{l}\text { Kerusakan / kehilangan material selama } \\
\text { penyimpanan }\end{array}$ & Penyedia Jasa & Penyedia Jasa & Penyedia Jasa & Penyedia Jasa \\
\hline \multicolumn{6}{|c|}{ H. Keselamatan dan Keamanan } \\
\hline RSK 29 & Gangguan keamanan & Penyedia Jasa & Penyedia Jasa & Bersama & Bersama \\
\hline RSK 30 & $\begin{array}{l}\text { Protes atau pelarangan pekerjaan oleh } \\
\text { warga sekitar }\end{array}$ & Ragu-Ragu & Penyedia Jasa & Bersama & Bersama \\
\hline RSK 31 & Kecelakaan pekerja & Penyedia Jasa & Penyedia Jasa & Ragu-Ragu & Ragu-Ragu \\
\hline RSK 32 & Terjadinya perselisihan antar pekerja & Penyedia Jasa & Penyedia Jasa & Ragu-Ragu & Ragu-Ragu \\
\hline \multicolumn{6}{|c|}{ I. Politik dan Regulasi } \\
\hline RSK 33 & Perubahan peraturan pemerintah & Ragu-Ragu & Ragu-Ragu & Ragu-Ragu & Bersama \\
\hline RSK 34 & $\begin{array}{l}\text { Rumitnya masalah perijinan atau } \\
\text { pembebasan lahan }\end{array}$ & Bersama & Ragu-Ragu & Bersama & Bersama \\
\hline RSK 35 & Ketidakstabilan moneter dan Inflasi & Ragu-Ragu & Ragu-Ragu & Bersama & Bersama \\
\hline
\end{tabular}

Dari Tabel 4 diatas dapat dilihat secara umum pengguna dan penyedia jasa konsisten dalam menentukan risiko yang harus dibagikan atau ditanggung oleh pengguna atau penyedia jasa.

Risiko yang berkaitan kondisi lokasi/site seperti bencana alam (seperti banjir, longsor, gempa bumi, dll), perubahan desain dan data desain tidak lengkap baik pengguna jasa maupun penyedia jasa sepakat berharap untuk menanggung alokasi secara bersama. Sedangkan risiko yang berkaitan dengan peralatan, untuk aktual alokasi pengguna jasa dan penyedia jasa sepakat untuk dialokasikan kepada penyedia jasa. Namun ekpektasi alokasi diputuskan secara ragu-ragu. Sebagian pengguna jasa dan penyedia jasa berharap risiko yang menyangkut peralatan 
ditanggung sepenuhnya oleh penyedia jasa sedangkan sebagian lainnya berharap risiko-risiko tersebut dapat ditanggung secara bersama.

Jika dibandingkan dengan hasil penelitian Andi (2006) mengenai alokasi risiko pada proyek konstruksi gedung di Indonesia menunjukan bahwa risiko yang diputuskan secara ragu-ragu adalah inflasi dan keadaan politik. Salah satu cara memitigasi risiko adalah dengan mengalokasikan risiko melalui klausul-klausul Kontrak Proyek Konstruksi. Bahwa sebagian risiko sudah diatur dalam kontrak standar. Dalam Syarat-Syarat Umum Kontrak (SSUK) dijelaskan bila terjadi keadaan kahar seperti bencana alam, bencana non alam, bencana sosial, pemogokan, kebakaran dan gangguan lainnya maka penyedia berhak mendapat perpanjangan waktu paling kurang sama dengan waktu terhentinya kontrak. Contoh lainnya adalah akses ke lokasi kerja. Dijelaskan dalam SSUK bahwa penyedia berkewajiban untuk menjamin akses pengguna jasa ke lokasi kerja dan lokasi lainnya dimana pekerjaan ini sedang atau akan dilaksanakan. Secara umum, jika diperhatikan kontrak konstruksi memang lebih dititik beratkan menjadi tanggung jawab penyedia. Hanya saja sebelum penandatanganan kontrak, pengguna dan penyedia seharusnya sudah mengetahui hak dan kewajiban sehingga masing-masing pihak memahami dengan baik tugas dan tanggung jawab nya.

\section{SIMPULAN}

Pengguna dan penyedia jasa memiliki persepsi masing-masing dalam menilai setiap faktor risiko. Faktor risiko yang paling sering terjadi adalah keadaan cuaca hujan lebat. Sedangkan risiko yang sangat berdampak terhadap waktu pelaksanaan konstruksi adalah rumitnya masalah perijinan atau pembebasan lahan. Responden konsisten dalam menentukan risiko yang harus dibagi atau ditanggung oleh pengguna atau penyedia jasa. Namun, ditemukan bahwa banyak risiko diputuskan secara ragu-ragu dan responden memiliki persepsi yang berbeda mengenai alokasi risiko.

\section{DAFTAR PUSTAKA}

Andi, (2006), The importance and allocation of risks in Indonesian construction projects, Construction Management and Economics, p69-80.

Flanagan, R., Norman, G., (1993). Risk Management and Construction. Cambridge: UniversityPress.

Honesti,dkk,. (2014). Identifikasi Faktor - Faktor Risiko yang Mempengaruhi Kinerja Biaya pada Proyek Irigasi di Kabupaten Kerinci, Jurnal Teknik Sipil Universitas Bung Hatta, Vol. 5, no. 3

Kodoatie R. J, Sugiyanto,. (2002). Banjir. Yogyakarta. Pustaka Pelajar.

Masril,dkk,. (2012). Faktor-Faktor yang Mempengaruhi Kinerja Penyedia jasa terhadap Waktu Pelaksanaan pada Pekerjaan Bidang Keairan di Kota Bukittinggi, Jurnal Teknik Sipil Universitas Bung Hatta, Vol.5, no.3

Nizamuddin, Masimin, I.A. Maji,. (2013). Faktor - Faktor Risiko yang Mempengaruhi Kinerja Tahap Pelaksanaan Proyek Irigasi (Studi Kasus di Provinci Aceh), Jurnal Teknik Sipil Unsyiah, Vol. 2, no. 1, Februari, p12-25, ISSN 2302-0253

Nugrahaeni, V. A., (2012), Analisis Risiko Lingkup Non Execuseable pada Tahap Pelaksanaan Proyek Pembangunan Stasiun Daerah Kantor X yang Berpengaruh Terhadap Perubahan Kinerja Proyek, Tesis Fakultas Teknik Program Studi Teknik Sipil Universitas Indonesia

Ratnaningsih, dkk,. (2014). Analisis Risiko Manajemen Konstruksi Pembangunan Waduk Bajulmati BanyuwangiJawa Timur, Seminar Nasional Teknik Sipil ITS Surabaya, ISSN 978-979-99327-9-2 